\title{
Pelatihan Pengolahan “Kerupuk PA'KUPAS” pada Masyarakat Panti Asuhan Setia Karya
}

\section{Training on Processing "Crackers PA'KUPAS" at the Setia Karya Orphanage Society}

Devi Novi Yanti, Program studi Pendidikan Teknologi Pertanian, Fakultas Teknik, Universitas Negeri Makassar, Email : devynovi5@gmail.com

Nurhikmah, Program studi Pendidikan Teknologi Pertanian, Fakultas Teknik, Universitas Negeri Makassar, Email : Hikmahassagaf11@gmail.com

Taufik Hidayat, Program studi Pendidikan Teknologi Pertanian, Fakultas Teknik, Universitas Negeri Makassar, Email : htaufiq754@gmail.com

\begin{abstract}
Abstrak
Kulit pisang merupakan limbah pertanian yang cukup mudah ditemukan dikota Makassar. Bertambahnya industri rumah tangga yang menghasilkan produk olahan pisang menyebabkan jumlah kulit pisang semakin banyak. Tujuan untuk meminimalisir limbah kulit pisang dengan cara memanfaatkannya menjadi sebuah produk yang bernilai sehingga muncullah inovasi dengan mengolah kulit pisang menjadi "Kerupuk Pa'KuPas" (Pangsit kulit pisang). Metode yang dilakuan dengan melaksanakan pelatihan pengolahan "Kerupuk Pa'KuPas" (Pangsit kulit pisang) pada masyarakat panti asuhan Setia Karya guna memberi bekal keterampilan sehingga nantinya dapat dimanfaatkan untuk membuka peluang kerja baik usaha mandiri maupun membuka lapangan pekerjaan untuk orang lain. Hasil Adanya perubahan perilaku masyarakat panti asuhan setia karya menjadi lebih produktif dan kegiatan ini dapat memberi bekal keterampilan bagi masyarakat panti asuhan setia karya.
\end{abstract}

Kata Kunci : panti asuhan, kerupuk pangsit, limbah kulit pisang.

\begin{abstract}
Banana skin is an agricultural waste that is easily found in the city of Makassar. Increasing the home industry that produces processed banana products causes the number of banana peels to increase. The aim of minimizing banana peel waste is to use it as a valuable product so that innovation emerges by processing banana peel into "Kerupuk Pa'KuPas" (Banana skin dumpling). The method is carried out by conducting training on "Kerupuk Pa'KuPas" (Banana skin dumpling) in Setia Karya orphanage communities to provide skills so that later it can be used to open up opportunities for work both independently and open employment opportunities for others. Results: The change in behavior of loyal orphanage works has become more productive and this activity can provide skills for loyal orphanage communities.
\end{abstract}

Keywords: orphanages, dumpling crackers, banana skin. 


\section{Latar Belakang}

Badan Pusat Statistik (BPS) menunjukkan jumlah penduduk Sulawesi Selatan terbaru tahun 2018 ini mencapai 8,7 juta jiwa. Jumlah penduduk itu adalah gabungan akumulasi dari 24 kabupaten kota di Sulawesi Selatan (BPS,2018). Jumlah penduduk Sulawesi Selatan paling banyak berada di Makasar dengan jumlah penduduk menembus 1,5 juta jiwa. Pertumbuhan penduduk yang besar dari tahun ke tahun ini memerlukan tambahan investasi dan sarana untuk mendukung kesejahteraan rakyat seperti sarana pendidikan, kesehatan, perekonomian dan lain sebagai lainnya. Pertumbuhan penduduk yang begitu pesat sangat mempengaruhi perekonomian suatu bangsa, karena kita lihat sekarang ini kepadatan penduduk di kota-kota besar di Indonesia salah satunya kota Makassar, mempengaruhi tingkat pendapatan penduduk, jumlah lowongan kerja yang semakin sedikit menyebabkan semakin banyak perilaku kriminalitas, salah satunya menintipkan anak ke panti asuhan. Hal ini sangat berkesinambungan dengan meningkatnya jumlah panti asuhan yang terdapat di kota - kota besar salah satunya kota Makassar yang memiliki 94 panti asuhan yang terdaftar di dinas sosial. Beberapa panti asuhan, kebanyakan remaja seusai pulang sekolah tidak memiliki kegiatan, dan para Pembina panti yang telah menyelesaikan tugasnya pun memiliki waktu luang yang banyak, sehingga tidak produktif. Kota Makassar merupakan kota yang terkenal memiliki beragam jajanan olahan pisang terbanyak dari kota lainnya. Produk olahan pisang yang cukup terkenal dikota Makassar adalah pisang ijo, pisang epe, pallu butung, barongko, sanggara balanda, pisang peppe, dan lain sebagainya.
Tanaman pisang merupakan tanaman holtikultura yang menjadi salah satu bahan ekspor yang baik dan sangat potensial bagi negara. Disamping itu pisang juga merupakan jenis tanaman yang setiap saat berbuah tanpa ada istilah musim. Tanaman pisang dapat dikatakan sebagai tanaman serbaguna. Akar, umbi (bonggol), batang, daun sampai kulitnya dapat dimanfaatkan untuk berbagai keperluan (Wakano, dkk. 2016). Kulit pisang kebanyakan masih merupakan limbah pertanian yang dibuang begitu saja sehingga sering menimbulkan pencemaran lingkungan. Oleh sebab itu perlu dicarikan solusi penanganannya dengan dimanfaatkan menjadi suatu bahan/produk makanan oleh industry (Hartono dan Pramudyo, 2013)

Menurut Wijaya (2013), pisang diketahui mengandung gizi tinggi dan sebagai sumber vitamin, mineral dan juga karbohidrat. Kandungan nutrisi lainnya seperti serat dan vitamin dalam buah pisang seperti vitamin A, B, dan C, dapat membantu memperlancar sistem metabolisme tubuh, meningkatkan daya tahan tubuh dari radikal bebas serta menjaga kondisi tetap kenyang dalam waktu lama. Semua unsur ini dapat bermanfaat sebagai sumber energi juga antibodi bagi tubuh manusia. Ketersediaan kulit pisang yang sangat melimpah di sekitar kita serta didukung oleh manfaatnya yang sangat baik bagi kesehatan, maka prospek usaha pengolahan kulit pisang sangat menjanjikan apalagi sekarang animo masyarakat untuk mengkonsumsi camilan yang bergizi, enak, lezat, dan sehat (Yulendra dan Muharis, 2018). Sejauh ini, kulit buah pisang biasanya hanya dimanfaatkan sebagai pakan ternak dan sebagai bahan baku pembuatan bioetanol. Kulit buah pisang juga dimanfaatkan sebagai masker anti jerawat 
karena diketahui memiliki kemampuan antibakteri (Saraswati, 2015). Pemanfaatan dan potensi kulit pisang sebagai bahan baku pembuatan produk bernilai jual harus terus digali dan dipelajari. Selain untuk mengurangi limbah, hal tersebut juga berguna untuk peningkatan pendapatan masyarakat dan peluang usaha skala rumah tangga (Rahmiati, dkk. 2017).

\section{Tujuan}

Sehubungan dengan uraian berikut, kami mencoba untuk mengurangi limbah kulit pisang, dengan cara memanfaatkan kulit pisang sebagai bahan baku utama dalam produk makanan, dan mengolahnya menjadi sesuatu yang bernilai ekonomis. Oleh karna itu, kami akan melaksanakan pelatihan pengolahan "Kerupuk Pa'KuPas" (Pangsit kulit pisang) pada masyarakat panti asuhan Setia Karya guna memberi bekal keterampilan sehingga nantinya dapat dimanfaatkan untuk membuka peluang kerja baik usaha mandiri maupun membuka lapangan pekerjaan untuk orang lain.

\section{Bahan dan Metode}

Kegiatan ini dibagi menjadi 3 tahapan yaitu tahapan awal (persiapan), tahap pelaksanaan, dan tahap akhir yang dilaksanakan selama 3 bulan. Adapun tahapan kegiatan yang dilaksanakan adalah sebagai berikut :

\section{A. Tahap Awal (Persiapan)}

Pada tahap ini tim pelaksana membuat perencanaan mengenai alat dan bahan yang akan digunakan, menentukan tempat pembuatan kerupuk pangsit kulit pisang, melakukan observasi mengenai industri rumah tangga produk olahan pisang, membuat logo kemasan,spanduk, brosur dan sertifikat serta pembuatan video tutorial pembuatan kerupuk $\mathrm{Pa}$ 'KuPas.

\section{B. Tahap Pelaksanaan}

Tahap pelaksanaan kegiatan ini dibagi ke dalam beberapa tahap yaitu :

\subsection{Penetapan daerah sasaran dan observasi lapangan}

Diawal tahap pelaksanaan dilakukan penetapan daerah sasaran yaitu panti asuhan setia karya karna perilaku masyarakat panti asuhan setia karya yang kurang produktif. Selain itu, disekitar panti asuhan banyak industri rumah tangga olahan pisang sehingga masyarakat panti asuhan lebih mudah mendapatkan limbah kulit pisang.

\subsection{Izin pelaksanaan}

Pada tahap ini tim pelaksana mengunjungi panti asuhan untuk menemui Pembina panti untuk meminta izin pelaksanaan untuk melakukan penyuluhan dan pelatihan kepada masyarakat panti asuhan setia karya

\subsection{Penyusunan materi dan persiapan pelatihan}

Selanjutnya menyusun materi terkait limbah kulit pisang beserta olahannya.Pokok - pokok materi yang akan tim pelaksana ajarkan meliputi :

1. Manfaat dan kandungan Kulit pisang

2. Inovasi produk yang dapat dibuat dari kulit pisang

3. Proses pembuatan kerupuk pangsit kulit pisang (Pa'KuPas).

Selain materi, tim pelaksana juga menyiapkan alat dan bahan yang akan digunakan dalam pembuatan kerupuk Pa'KuPas serta tim pelaksana juga 
membuat logo kemasan,spanduk, brosur dan sertifikat serta pembuatan video tutorial pembuatan Kerupuk Pa'KuPas. Adapun proses pembuatan Kerupuk Pa'KuPas yaitu :

\section{Peralatan}

Adapun peralatan yang dipergunakan yaitu:

1. Blender

2. Timbangan

3. Mangkuk

4. Wajan

5. Spatula

6. Panci

7. Sendok

8. Sendok ukur

9. Saringan

10. Pisau

\section{Bahan}

Dalam satu adonan membutuhkan bahan seperti :

1. 200 gr kulit pisang

2. 120 gr udang

3. 50 gr tepung kanji

4. 5 siung bawang putih

5. 2 gr merica bubuk

6. Kulit pangsit

7. 1 sdt gula

8. $1 / 2$ sdt garam

9. Minyak goring

10. Penyedap rasa

11. Air secukupnya untuk merekatkan kulit pangsit

\section{Proses Pembuatan}

1. Siapkan 4 buah kulit pisang

2. Cuci kulit pisang pada air yang mengalir sehingga bersih dan terhindar dari kotoran yang melekat.
3. Rebus kulit pisang \pm 5 menit. Tujuan perebusan ini mematangkan dan melembutkan pisang sehingga mudah diblender dan memberikan cita rasa yang enak serta menghilangkan getah yang terdapat dikulit pisang.

4. Setelah matang, kulit pisang diangkat dan tiriskan, lalu diamkan hingga dingin

5. Selanjutnya, Ambil kulit bagian dalam pisang lalu masukkan kedalam blender dan tambahkan udang, bawang putih dan merica.

6. Lalu adonan pangsit yang telah halus tuang kedalam mangkuk kemudian tambahkan tepung kanji dan aduk hingga rata

7. Ambil kulit pangsit lalu isi dengan adonan pangsit. Bentuk sesuai selera, rekatkan pinggiran kulit pangsit dengan menggunakan air

8. Panaskan minyak dengan api yang sedang. Setelah panas, masukkan kulit pangsit lalu goreng hingga berubah warna. Kerupuk pangsit kulit pisang siap untuk dihidangkan.

\section{Pengemasan}

Kerupuk Pa'KuPas dikemas dalam kemasan plastik, kemudian disegel dengan rapat. Kerupuk Pa'KuPas tahan selama 3 hari dalam suhu ruang. Kemasan plastik ini diberikan brand nama produk sebagai tanda pengenal dan pembeda dari jenis kerupuk pangsit lainnya. Brand ini juga merupakan nilai tambah bagi kerupuk Pa'KuPas sehingga konsumen lebih mudah mengenali kerupuk Pa'KuPas. Selain mencantumkan nama, terdapat tanggal kadaluarsa dan komposisi bahan 
agar pembeli tidak ragu untuk mengkonsumsi

\subsection{Sosialisasi dan pelaksanaan program} kepada masyarakat panti asuhan setia karya

Ditahap ini tim pelaksana melakukan sosialisasi mengenai limbah kulit pisang berdasarkan materi yang telah dibuat serta melakukan pelatihan untuk masyarakat panti asuhan.

\subsection{Tahap evaluasi}

Pada tahap ini dilakukan dengan melihat tingkat keberhasilan kegiatan. Evaluasi dilaksanakan pada awal kegiatan, berdasarkan lembar respon (kuisioner) yang telah dibagikan kepada setiap peserta pelatihan. Sementara pada akhir kegiatan, dilakukan dengan membuat testimoni setelah adanya pelatihan ini.

\section{Tahap Akhir}

Hal terakhir yang dilakukan adalah menganalisis pencapaian tujuan yang dicapai, keberlangsungan program selanjutnya serta menyusun laporan kemajuan.

\section{Hasil dan Pembahasan}

A. Hasil

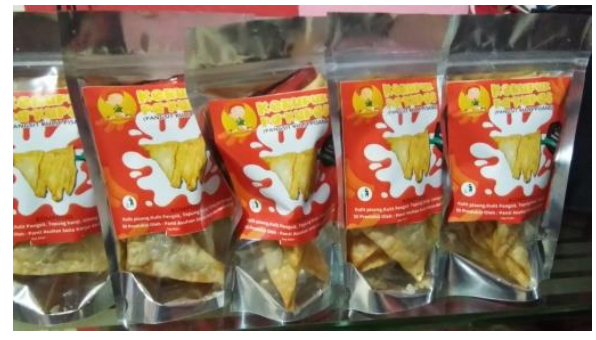

Gambar 1. Kerupuk Pa'KuPas

\section{B. Pembahasan}

Kegiatan pelatihan pengolahan kerupuk $\mathrm{Pa}$ 'KuPas yang dilaksanakan di panti asuhan setia karya dapat dinilai sudah berjalan dengan baik pasalnya semua kegiatan yang dilakukan sesuai dengan jadwal yang telah ditetapkan.

1. Penetapan daerah sasaran dan observasi lapangan

Penetapan daerah sasaran yang tujuannya adalah mengetahui permasalahan dan potensi yang ada pada sekitar panti asuhan tersebut.

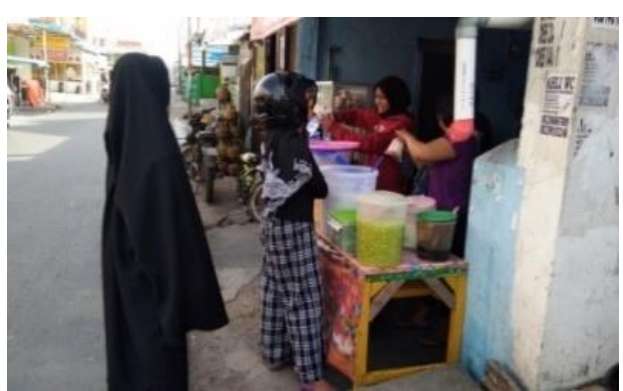

Gambar 2. Observasi Lapangan

2. Izin pelaksanaan

Setelah permasalahan dan potensi tersebut benar - benar dapat dimanfaatkan, langkah selanjutnya adalah melakukan izin pelaksanaan kepada pembina panti. Respon dari Pembina panti sangat baik dan mendukung adanya program guna sebagai bekal keterampilan untuk semua masyarakat panti.

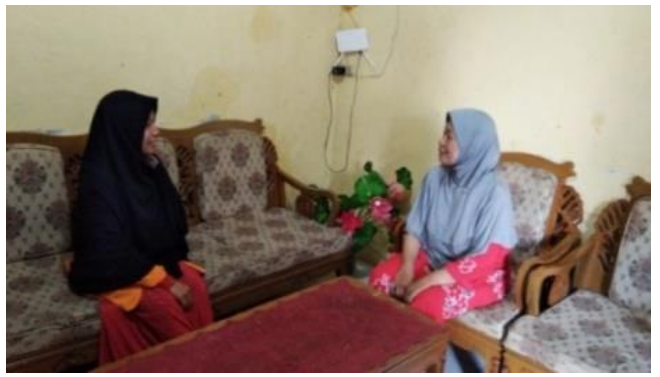

Gambar 3. Izin pelaksanaan 
3. Desain logo kemasan kerupuk Pa'KuPas Kemasan kerupuk Pa'KuPas diberikan brand nama produk sebagai tanda pengenal dan pembeda dari jenis kerupuk pangsit lainnya. Brand ini juga merupakan nilai tambah bagi Kerupuk Pa'KuPas sehingga konsumen lebih mudah mengenali Kerupuk Pa'KuPas. Selain mencantumkan nama, logo kemasan juga mencantum tanggal kadaluarsa dan komposisi bahan agar pembeli tidak ragu untuk mengkonsumsi.

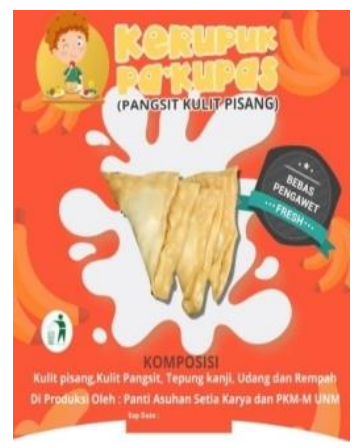

Gambar 4. Desain logo kemasan Kerupuk Pa'KuPasPelaksanaan program

Sosialisasi dilakukan pada tanggal 12 juni 2019 yang diikuti oleh semua masyarakat panti, respon masyarakat panti dalam pengenalan awal sangat baik, mereka mendukung sepenuhnya program ini. Hal tersebut diketahui dari kuisioner yang diberikan kepada masyarakat panti.

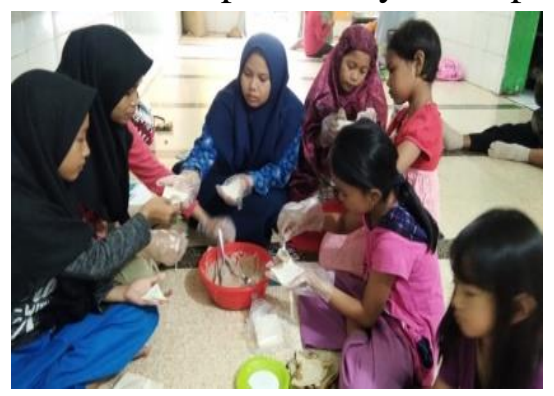

Gambar 5. Pelaksanaan Program

4. Pemahaman Masyarakat

Sebelum adanya pelatihan pengolahan kerupuk Pa'KuPas ini, masyarakat panti asuhan tidak mengetahui manfaat dan kandungan dari kulit pisang dan mereka hanya mengetahui kulit pisang adalah limbah yang tidak dapat dimanfaatkan namun setelah adanya pelatihan ini, mereka akhirnya memiliki pengetahuan dan keterampilan mengenai limbah kulit pisang dan sudah dapat menjadi sebuah produk yang dapat dijadikan sebuah peluang usaha.

5. Penilaian masyarakat panti terhadap kerupuk Pa'KuPas

Adapun tanggapan dari beberapa masyarakat panti yang sangat positif salah satunya Pembina. Mereka sangat mengapresiasi mengenai program yang tim pelaksana buat. Ini dilandaskan dengan tanggapan - tanggapan mereka sesuai dengan pelatihan ini. "Selama ini anak anak disini kalau makan bakso biasa kita beli kerupuk pangsitnya, dengan adanya pelatihan ini kita bisa buat sendiri karna kita sudah tau ilmunya dan rasa kerupuk ini juga enak serta bisa menghemat pengeluaran dan dapat menjadi sebuah peluang usaha" ujar Pembina panti asuhan. "Saat melakukan pelatihan ini, kita yang awalnya tidak tau menjadi tau cara membuatnya dan bisa menjadi contoh untuk dijadikan sebagai peluang usaha" ungkap Imran, salah satu remaja panti yang mengikuti pelatihan.

Setelah melaksanakan kegiatan ini, PKM ini memiliki potensi yang menjanjikan baik dai segi pengetahuan maupun terhadap penerapannya. Berikut beberapa potensi yang dapat diperoleh :

1. Manfaat Artikel Ilmiah

Dalam pelaksanaannya, kami melihat respon dan antusias masyarakat panti mengenai pengolahan kerupuk pangsit kulit pisang (Pa'KuPas) ini 
JPTP Jurnal Pendidikan Teknologi Pertanian sangat baik. Maka dari itu kegiatan ini dapat dirujuk menjadi sebuah artikel ilmiah dan dimuat dijurnal sebagai bentuk referensi kepada masyarakat.

2. Peluang Perolehan Paten

Kerupuk Pangsit yang telah ada berbeda dengan kerupuk pangsit kulit pisang karena kerupuk Pa'KuPas ini memanfaatkan limbah kulit pisang guna meminimalisir limbah kulit pisang di kota Makassar. Selain itu, Kerupuk Pa'KuPas ini perpaduan antara kulit pisang dengan udang sehingga memiliki rasa yang khas serta cara pembuatannya cukup simple dan tidak membutuhkan waktu yang lama. Hingga saat ini belum ada kerupuk pangsit yang seperti ini, sehingga Kerupuk Pa'KuPas sangat berpeluang untuk memperoleh paten.

3. Manfaat dari berbagai aspek

- Dari segi pengetahuan, pengolahan kerupuk Pa'KuPas ini dapat dijadikan bekal keterampilan bagi setiap masyarakat panti asuhan.

- Dari segi sosial,pelatihan pengolahan kerupuk Pa'KuPas ini dapat dimanfaatkan peluang usaha sehingga mengurangi jumlah pengganguran di panti asuhan setia karya

- Dari segi ekonomi, kerupuk Pa'KuPas dapat bermanfaat sebagai mata pencaharian masyarakat yang dapat mendatangkan keuntungan ekonomis karna tidak memerlukan biaya yang besar.

4. Potensi Pengembangan Usaha

Dengan adanya produk kerupuk Pa'KuPas ini dapat meminimalisir limbah kulit pisang yang terdapat disekitar panti asuhan, memiliki rasa yang khas, proses pembuatannya cukup mudah dan tidak memerlukan waktu yang lama serta biaya yang tidak besar
Volume 5, 2019

sehingga kerupuk Pa'KuPas ini dapat menjadi peluang usaha yang cukup menjanjikan karna di Makassar belum ada yang membuat produk tersebut.

\section{Simpulan}

Adanya perubahan perilaku masyarakat panti asuhan setia karya menjadi lebih produktif dan kegiatan ini dapat memberi bekal keterampilan bagi masyarakat panti asuhan setia karya sehingga mengurangi jumlah pengangguran yang terdapat di panti asuhan Setia Karya serta dengan adanya keberlanjutan kegiatan ini, masyarakat panti asuhan Setia Karya dapat membuka usaha mandiri dan membuka lapangan pekerjaan bagi remaja panti asuhan setia karya.

\section{Daftar Pustaka}

Badan Pusat Statistik (BPS). 2018. Badan Pusat Statistik kota makassar. https://makassarkota.bps.go.id/.

Diakses tanggal 22 juni 2019.

Hartono, A dan Pramudyo B. 2013. Pelatihan Pemanfaatan Limbah Kulit Pisang Sebagai Bahan Dasar Pembuatan Kerupuk. Vol 2(3) : 198 203

Rahmiati, Chalis F, dan Dewi N. 2017. Pembuatan Selai Kulit Pisang. Vol 2(1): $78-83$

Saraswati, 2015. Uji Aktifitas Antibakteri Ekstrak Etanol Limbah Kulit Pisang Kepok Kuning terhadap Bakteri Penyebab Jerawat. Skripsi. Jakarta : UIN Syarif Hidayatullah

Wakano,D., E. Samson, dan L. D. Tetelepta. 2016. Pemanfaatan Limbah Kulit Pisang Sebagai Bahan Olahan Kripik Dan Kue Donat di Desa Batu 
JPTP Jurnal Pendidikan Teknologi Pertania

Merah Kota Ambon. Vol 5(2) : 152 158

Wijaya.2013. Manfaat Buah Asli Indonesia. PT. Gramedia. Jakarta

Yulendra, L dan Muharis A. 2018. Pemanfaatan Kulit Pisang Untuk Pembuatan Brokupis (Brownies Kulit Pisang). Vol 12(12): ISSN 1978-3787 